\title{
Gambaran Derajat Merokok Pada Penderita PPOK di Bagian Paru RSUP Dr. M. Djamil
}

Fadhil el Naser ${ }^{1}$, Irvan Medison ${ }^{2}$, Erly $^{3}$

\begin{abstract}
Abstrak
Penyakit Paru Obstuktif Kronik (PPOK) adalah penyakit dengan karakteristik keterbatasan saluran napas yang tidak sepenuhnya reversibel dan dapat dicegah. Indonesia merupakan salah satu negara berkembang yang memiliki jumlah perokok aktif yang tinggi. Tujuan penelitian ini adalah untuk mengetahui gambaran derajat merokok pada penderita PPOK di Bagian Paru Rumah Sakit Umum Pusat Dr. M. Djamil Padang. Ini adalah penelitian deskriptif retrospektif dengan menggunakan data rekam medik penderita merokok dengan yang dirawat di Bagian Paru Rumah Sakit Umum Pusat Dr. M. Djamil. Data sekunder diambil dari rekam medik penderita Penyakit Paru Obstruktif Kronik (PPOK) yang dirawat di Bagian Paru Rumah Sakit Umum Pusat dari 1 Januari 2013 sampai 31 Desember 2013. Data diolah secara manual dan disajikan dalam bentuk tabel distribusi frekuensi. Sebanyak 20 subjek didapatkan nilai indeks brinkman berat sebanyak 15 orang. Setelah dilakukan uji statistik didapatkan hubungan yang signifikan antara derajat merokok dengan derajat keparahan PPOK $(p=0,033)$ dan korelasi yang kuat antara keduanya $(r=0,577)$. Terdapat hubungan yang signifikan dan korelasi yang kuat antara derajat merokok dengan derajat keparahan PPOK.
\end{abstract} Kata kunci: merokok. indeks Brinkman, PPOK

\begin{abstract}
COPD is a disease with airway limitation characteristic. That is not fully reversible and can be prevented. Smoking is the leading cause of COPD. Indonesia is one of the developing countries that have a high number of active smokers. The increase in prevalence is also occurred in the province of West Sumatra, which increased from $30.2 \%$ in 2007 to $38.4 \%$ in 2010. The objective of this study was to describe the degree of smoking in patients with COPD in Pulmonary Section General Hospital Dr. M. Djamil. This study used a retrospective descriptive design using medical record data of smoker patients with Chronic Obstructive Pulmonary Disease (COPD) who were treated in the Pulmonary Section General Hospital Dr. M. Djamil. The data was taken from the secondary status of patients with Chronic Obstructive Pulmonary Disease (COPD) who were treated in Pulmonary Section General Hospital from January 1, 2013 to December 31, 2013 that recorded in the medical record. Data processed manually from the status of COPD patients and were presented in the form of frequency distribution table. From 20 subjects obtained that 15 samples were classified to severe Brinkman index. Statistical tests found a significant relationship between the degree of smoking with COPD severity $(p=0.033)$ and a strong correlation between the two $(r=0.577)$. There is a significant relationship and strong correlation between the degree of smoking with COPD severity.
\end{abstract}

Keywords: smoking, Brinkman Index, COPD

Affiliasi penulis: 1.Fakultas Kedoktera Paru Fakultas Kedokteran Unand, 3.Bagian Mikrobiologi Fakultas Kedokteran Unand Korespondensi: Fadhil el Naser, email: me.fadhil@yahoo.com, Telp: 081270390542

\section{PENDAHULUAN}

PPOK adalah penyakit dengan karakteristik keterbatasan saluran napas yang tidak sepenuhnya reversible dan dapat dicegah. Keterbatasan saluran 
napas tersebut biasanya progresif dan berhubungan dengan respons inflamasi dikarenakan bahan yang merugikan atau gas. ${ }^{1}$ Penyakit Paru Obstruktif Kronik (PPOK) bukan penyakit tunggal tetapi merupakan istilah umum yang digunakan untuk menggambarkan penyakit paru kronisyang menyebabkan keterbatasan dalam aliran udara paru. Istilah lebih umum bronkitis kronis dan emfisema tidak lagi digunakan, tetapi sekarang termasuk dalam diagnosis PPOK. ${ }^{2}$

Secara global diperkirakan sekitar 65 juta orang menderita PPOK dan 3 juta meninggal karena PPOK pada tahun 2005, dengan mewakili 5\% dari seluruh kematian. Total kematian akibat PPOK diproyeksikan akan meningkat lebih dari $30 \%$ pada 10 tahun mendatang. Peningkatan secara drastis pada dua dekade mendatang diperkirakan di negara-negara Asia dan Afrika karena peningkatan pemakaian tembakau. ${ }^{3}$ Meningkatnya masalah merokok membuat masalah PPOK menjadi semakin serius. Diperkirakan $22 \%$ dari populasi global yang berumur lebih dari 15 tahun merupakan perokok. ${ }^{4}$

Di Indonesia tidak ada data yang akurat tentang kekerapan PPOK. Hasil survei penyakit tidak menular oleh Dirjen PPM \& PL di lima rumah sakit propinsi di Indonesia (Jawa Barat, Jawa Tengah, Jawa Timur, Lampung, dan Sumatera Selatan) pada tahun 2004, menunjukkan PPOK menempati urutan pertama penyumbang angka kesakitan (35\%), diikuti asma bronkial (33\%), kanker paru (30\%) dan lainnya (2\%). ${ }^{5}$ Berdasarkan studi morbiditas dalam SUSENAS (2001), proporsi penderita sekitar 10\% dan menduduki peringkat ke-2 sebagai penyebab kematian di Indonesia (PMR 26,4\%).

Ada beberapa faktor risiko terjadinya PPOK yaitu merokok, usia, jenis kelamin, hiperesponsif saluran pernafasan, infeksi jalan nafas, pemaparan akibat kerja, polusi udara, status sosial dan faktor genetik. Sebuah penelitian dilakukan dari 1990 sampai 2004 pada 28 negara mendapatkan prevalensi PPOK lebih tinggi pada pasien perokok dibandingkan bukan perokok. ${ }^{7}$ Menurut data WHO tahun 2008 didapatkan merokok merupakan penyebab utama PPOK. $^{8}$ Merokok dikatakan sebagai faktor risiko utama terjadinya PPOK. ${ }^{1}$

Terkait dengan hal itu, Indonesia merupakan salah satu negara berkembang yang memiliki jumlah perokok aktif yang tinggi. Pada tahun 2008, World Health Organization (WHO) telah menetapkan Indonesia sebagai negara terbesar ketiga di dunia sebagai pengguna rokok. ${ }^{8}$ Data dari Riset Kesehatan Dasar (Riskesdas) oleh Kementrian Kesehatan Republik Indonesia, jumlah perokok aktif di Indonesia meningkat dari $28,2 \%$ pada tahun 2007 menjadi $34,7 \%$ pada tahun 2010. Peningkatan prevalensi ini juga terjadi di Provinsi Sumatera Barat, dimana meningkat dari 30,2\% pada tahun 2007 menjadi $38,4 \%$ pada tahun 2010 . $^{9}$

Hasil penelitian Setiyanto di ruang rawat inap RS Persahabatan Jakarta selama April 2005 sampai April 2007 menunjukkan bahwa dari 120 penderita PPOK, usia termuda adalah 40 tahun dan tertua adalah 81 tahun. Dilihat dari riwayat merokok, hampir semua pasien adalah bekas perokok sebanyak 109 penderita dengan proporsi sebesar (90,83\%). ${ }^{10}$ Menurut hasil penelitian Shinta di RSU dr Soetomo Surabaya pada tahun 2006 menunjukkan bahwa dari 46 penderita PPOK, 29 orang diantaranya (63\%) adalah perokok. ${ }^{11}$ Penelitian Yolandha di ruang bangsal paru RSUP Dr. M. Djamil Padang periode Januari 2009 sampai Desember 2011, dari 120 penderita PPOK dapat dilihat Indeks Brinkman penderita dengan hasil 86 orang diantaranya $(71,7 \%)$ menunjukkan nilai Indeks Brinkman berat, 26 orang $(21,7 \%)$ dengan nilai sedang, dan 4 orang (3,3\%) dengan nilai ringan. ${ }^{12}$

\section{METODE}

Jenis penelitian adalah deskriptif retrospektif dengan menggunakan data rekam medik penderita merokok dengan Penyakit Paru Obstuktif Kronik (PPOK) yang dirawat di Bagian Paru Rumah Sakit Umum Pusat Dr. M. Djamil. Penelitian ini dilakukan pada bulan Juni dengan mengamati data rekam medis pasien Penyakit Paru Obstruktif Kronik (PPOK) di Bagian Paru Rumah Sakit Umum Pusat Dr. M. Djamil.

Populasi penelitian ini adalah seluruh data rekam medik pasien Penyakit Paru Obstuktif Kronik (PPOK) periode 1 Januari 2013 sampai 31 Desember 2013. Subjek pada penelitian ini adalah bagian populasi yang memenuhi kriteria inklusi dan ekslusi. Data sekunder dari status penderita Penyakit Paru Obstruktif Kronik (PPOK) yang dirawat di Bagian Paru 
Rumah Sakit Umum Pusat dari tanggal 1 Januari 2013 sampai 31 Desember 2013 yang terdata pada rekam medik. Data diolah secara manual dari status pasien PPOK dan disajikan dalam bentuk tabel distribusi frekuensi.

\section{HASIL}

Penelitian ini dilakukan terhadap penderita PPOK di bagian paru RSUP $\mathrm{Dr}$ M Djamil periode 2013. Jumlah subjek yang didapatkan setelah menggunakan metode total sampling adalah 69 orang yang terdiri dari 62 orang berjenis kelamin laki-laki dan 7 orang perempuan, hanya 20 orang yang memenuhi kriteria inklusi.

Berdasarkan penelitian yang telah dilaksanakan, diperoleh informasi mengenai gambaran karakterikstik subjek penelitian sebagai berikut :

Tabel 1. Karakteristik data berdasarkan umur, jenis kelamin, pekerjaan, pendidikan

\begin{tabular}{lcc}
\hline \multicolumn{1}{c}{ Karakteriistik } & $\mathbf{n}$ & $\%$ \\
\hline $\begin{array}{l}\text { Umur (rata-rata) } \\
\text { Jenis kelamin }\end{array}$ & 6,85 & \\
$\quad$ Laki-laki & 20 & 100 \\
$\quad$ Perempuan & 0 & 0 \\
Pekerjaan & & \\
$\quad$ Buruh & 10 & 50 \\
$\quad$ Supir & 4 & 20 \\
$\quad$ Wiraswasta & 3 & 15 \\
$\quad$ Petani & 2 & 10 \\
$\quad$ Tidak bekerja & 1 & 5 \\
Pendikan & & \\
SD & 6 & 30 \\
SLTP & 6 & 30 \\
SLTA & 8 & 40 \\
Perguruan Tinggi & - & \\
\hline
\end{tabular}

Tabel 1 menggambarkan umur rata-rata penderita PPOK adalah 61,85 dan semua penderita berjenis kelamin laki-laki. Proporsi pekerjaan tertinggi penderita PPOK adalah buruh dengan presentase $50 \%$. Proporsi pendidikan tertinggi adalah SLTA dengan presentase $40 \%$.

Gambaran derajat keparahan penyakit pada penderita PPOK, diperoleh informasi sebagaimana tercantum dalam Tabel 2.
Tabel 2. Gambaran derajat keparahan penyakit pada penderita PPOK di RSUP Dr. M. Djamil

\begin{tabular}{lcc}
\hline Derajat keparahan & f & $\%$ \\
\hline Ringan & 5 & 25 \\
Sedang & 5 & 25 \\
Berat \& sangat berat & 10 & 50 \\
\hline
\end{tabular}

Pada Tabel 2 dapat dilihat derajat keparahan penderita PPOK terbanyak adalah derajat berat dan sangat berat dengan jumlah 10 orang (50\%).

Tabel 3. Gambaran derajat merokok pada penderita PPOK di RSUP Dr. M. Djamil

\begin{tabular}{lcc}
\hline Derajat merokok & $\mathbf{f}$ & $\%$ \\
\hline Ringan & 1 & 5 \\
Sedang & 4 & 20 \\
Berat & 15 & 75 \\
\hline & 20 & 100 \\
\hline
\end{tabular}

Berdasarkan Tabel 3 dapat dilihat derajat merokok penderita PPOK yang tertinggi dengan derajat berat $(75 \%)$, diikuti derajat sedang $(20 \%)$ dan terendah derajat ringan (5\%).

Tabel 4. Gambaran derajat keparahan penyakit penderita PPOK berdasarkan derajat merokok di RSUP Dr. M. Djamil

\begin{tabular}{|c|c|c|c|c|c|c|}
\hline \multirow{3}{*}{$\begin{array}{l}\text { Derajat } \\
\text { Merokok }\end{array}$} & \multicolumn{6}{|c|}{ Derajat PPOK } \\
\hline & \multicolumn{2}{|c|}{ Ringan } & \multicolumn{2}{|c|}{ Berat } & \multicolumn{2}{|c|}{$\begin{array}{c}\text { Berat \& } \\
\text { sangat berat }\end{array}$} \\
\hline & $f$ & $\%$ & f & $\%$ & $\mathbf{f}$ & $\%$ \\
\hline Ringan & 1 & 20 & - & 0 & - & 0 \\
\hline Sedang & 1 & 20 & 3 & 60 & - & 0 \\
\hline \multirow[t]{2}{*}{ Berat } & 3 & 60 & 2 & 40 & 10 & 100 \\
\hline & 5 & 100 & 5 & 100 & 10 & 100 \\
\hline
\end{tabular}

Pada Tabel 4 dapat dilihat bahwa dari seluruh penderita PPOK derajat ringan, sebanyak 1 orang (20\%) dengan derajat merokok ringan, 1 orang (20\%) derajat merokok sedang, dan 3 orang $(60 \%)$ derajat merokok berat. Sebanyak 3 orang (60\%) dengan derajat merokok sedang, dan 2 orang (40\%) dengan derajat merokok berat. Penderita PPOK derajat berat dan sangat berat memiliki derajat merokok berat dengan proporsi 10 orang (100\%). 
Uji chi-square dan Pearson dilakukan untuk mengetahui hubungan antara derajat merokok dengan derajat keparahan PPOK dan koefisien korelasi antara keduanya.

Tabel 5. Hubungan derajat merokok dengan derajat keparahan PPOK

\begin{tabular}{lcccccc}
\hline Derajat & \multicolumn{2}{c}{ Derajat keparahan } & & & \\
\cline { 2 - 4 } & $\begin{array}{c}\text { Sedang ke } \\
\text { bawah }\end{array}$ & $\begin{array}{c}\text { Berat ke } \\
\text { atas }\end{array}$ & $\mathbf{n}$ & $\mathbf{p}$ & $\mathbf{r}$ \\
\hline $\begin{array}{l}\text { Ringan } \\
\begin{array}{l}\text { Sedang } \\
\text { keatas }\end{array}\end{array}$ & 1 & 0 & 1 & & & \\
\hline
\end{tabular}

Berdasarkan hasil uji chi-square didapatkan nilai $p=0,033$ dan dari uji korelasi Pearson didapatkan koefisien korelasi $(r)=0,577$.

\section{PEMBAHASAN}

Karakteristik sampel pada penelitian ini dilihat dari jenis kelamin, umur dan pekerjaan serta pendidikan. Berdasarkan jenis kelamin, seluruh sampel pada penelitian ini adalah laki-laki. Hal ini sesuai dengan hasil penelitian oleh Rahmatika yang menyatakan bahwa penderita PPOK terbanyak adalah laki-laki dengan presentase $71,9 \%$ dari 139 sampel. $^{13}$

Kelompok umur pada umumnya adalah kelompok 60 tahun keatas yaitu sebanyak 11 orang $(55 \%)$, dan hanya 1 orang $(5 \%)$ yang berumur kecil dari 50 tahun. Hal ini sesuai dengan penelitian Shinta yang menyatakan bahwa kelompok umur terbanyak penderita PPOK adalah 60 tahun keatas dengan proporsi $84,8 \%$ dari 46 sampel. $^{11}$ Didukung juga oleh penelitian Rahmatika yang menyatakan bahwa penderita PPOK terbanyak berumur 60 tahun keatas dengan proporsi $57,5 \%$ dari 139 sampel. $^{13}$ Hasil ini berhubungan dengan penurunan fungsi paru yang lebih cepat menurun pada orang yang masih terus merokok setelah berumur lebih dari 45 tahun. ${ }^{14}$

Kategori pendidikan terbanyak adalah SLTA sebanyak 8 orang (40\%). Hal ini sesuai dengan penelitian Rahmatika (2009) yang menyatakan pendidikan terbanyak penderita PPOK adalah SLTA dengan proporsi 29,6\% dari 139 sampel.

Pekerjaan penderita PPOK yang terbanyak adalah buruh dengan proporsi $50 \%$ dan yang terendah tidak bekerja dengan proporsi $5 \%$. Hal ini dapat dikaitkan dengan faktor resiko PPOK. Umumnya pekerja yang bekerja di lingkungan berdebu dan tinggi polusi udara akan meningkatkan resiko PPOK. ${ }^{15}$

Derajat keparahan penyakit terbanyak adalah derajat berat dan sangat berat sebanyak 10 orang dengan presentase $50 \%$. Hal ini sejalan dengan penelitian Setiyanto di Rumah Sakit Persahabatan Jakarta yang menyatakan derajat keparahan penyakit PPOK terbanyak adalah derajat berat dengan presentase $61,67 \%$ dari 120 sampel. $^{10}$ Penelitian Rahmatika juga menyatakan derajat keparahan penyakit PPOK terbanyak adalah derajat berat dengan presentase $64,1 \%$ dari 139 sampel. $^{13}$

Hal ini juga berhubungan dengan hasil penelitian terkait umur yang mendapatkan penderita PPOK terbanyak adalah berumur 60 tahun keatas dengan teori yang menyatakan penurunan faal paru yang lebih cepat pada perokok yang masih terus merokok pada umur 45 tahun lebih. Faal paru yang menurun secara signifikan akan memperberat derajat keparahan PPOK seiring bertambahnya usia. Resiko untuk menderita PPOK bergantung pada dosis merokok, yang dipengaruhi oleh umur saat seseorang mulai merokok, jumlah rokok yang dihisap dalam sehari dan berapa lama orang tersebut merokok. ${ }^{1}$ Dosis tersebut dapat dihitung dengan nilai Indeks Brinkman yaitu perkalian antara jumlah batang rokok yang dihisap dalam sehari dengan lama merokok dalam tahun. ${ }^{16}$

Nilai indeks brinkman penderita PPOK dengan hasil indeks brinkman berat sebanyak 15 orang dengan presentase $75 \%$. Hal ini sesuai dengan penelitian Yolandha di bangsal paru RSUP M. Djamil yang menyatakan indeks brinkman pada penderita PPOK yang terbanyak adalah derajat berat dengan presentase $71,7 \%$ dari 120 sampel. $^{12}$

Hasil ini juga didukung oleh kepustakaan yang menyatakan merokok merupakan faktor resiko utama seseorang menderita PPOK. ${ }^{1}$ Semakin tinggi derajat merokok seseorang, maka akan semakin banyak orang tersebut terpapar berbagai zat yang dianggap toksik oleh tubuh pada saluran pernafasan yang akan berujung kepada penurunan fungsi faal paru yang lebih cepat dibanding bukan perokok

Berdasarkan penelitian ini dapat dilihat bahwa dari seluruh penderita PPOK derajat ringan, sebanyak 
satu orang (20\%) dengan derajat merokok ringan, satu orang $(20 \%)$ derajat merokok sedang, dan tiga orang $(60 \%)$ derajat merokok berat. Dari seluruh penderita PPOK dengan derajat sedang, sebanyak tiga orang $(60 \%)$ dengan derajat merokok sedang, dan dua orang (40\%) dengan derajat merokok berat. Dari seluruh penderita PPOK derajat berat dan sangat berat, dapat dilihat seluruh penderita memiliki derajat merokok berat dengan proporsi 10 orang (100\%).

Hasil uji statistik menggunakan uji chi-square didapatkan nilai $p=0,033$ dan uji korelasi Pearson didapatkan koefisien korelasi $=0,577$. Hasil ini menunjukkan terdapat hubungan yang signifikan antara derajat merokok dengan derajat keparahan PPOK, dan korelasi yang kuat antara keduanya.

Hasil penelitian ini sesuai dengan penelitian Prabaningtyas menggunakan metode analitik observasional dengan menggunakan pendekatan case control yang menunjukkan terdapat hubungan yang signifikan antara derajat merokok dengan kejadian PPOK (OR $=2,89, \mathrm{p}=0,008) .{ }^{17} \mathrm{Hal}$ ini juga didukung oleh penelitian Nugraha dengan metode analitik observasional dengan menggunakan pendekatan case control yang menyatakan adanya hubungan yang kuat antara derajat merokok dengan derajat PPOK (OR = $8, p=0,025)^{18}$

\section{KESIMPULAN}

Terdapat hubungan yang signifikan dan korelasi yang kuat antara derajat merokok dengan derajat keparahan PPOK.

\section{UCAPAN TERIMA KASIH}

Terima kasih yang sedalam-dalamnya kepada semua pihak atas arahan, bimbingan dan motivasi dalam penelitian ini.

\section{DAFTAR PUSTAKA}

1. Global Initiative for Chronic Obstructive Lung Disease (GOLD). Global strategy for diagnosis, management, and prevention of chronic obstructive pulmonary disease. Rilis Berita [serial online] 2011 (diunduh 16 Februari 2014).Tersedia dari: URL: HYPERLINK http://www.goldcopd.org/guidelinesglobal-strategy-for-diagnosis-management.html.
2. WHO. Burden of COPD. Rilis Berita [serial online] 2014 (diunduh pada 13 februari 2014). Tersedia dari: URL: HYPERLINK http://www.who.int/ respiratory/copd/burden/en/

3. WHO. The top ten cause of death 2004. Rilis Berita [serial online] 2005 (diunduh 13 februari 2014). Tersedia dari: URL: HYPERLINK http://www. who.int/whr/

4. WHO. Global status report on noncommunicable diseases 2010. Rilis Berita [serial online] 2011 (diunduh 14 Februari 2014). Tersedia dari: URL: HYPERLINK http://www.who.int/nmh/publications/ ncd report2010/en/

5. Departemen Kesehatan Republik Indonesia. Profil kesehatan Indonesia 2004. Jakarta: DEPKES RI; 2004.

6. Departemen Kesehatan Republik Indonesia. Profil kesehatan Indonesia 2001. Jakarta: DEPKES RI; 2002.

7. National Institute of Health National Heart, Lung, and Blood Institute. Chronic obstructive pulmonary disease. Rilis Berita [serial online] 2005 (diunduh 14 Februari 2014). Tersedia dari: URL: HYPERLINK http://www.nhlbi.nih.gov /health/prof/ lung/copd/copd wksp

8. WHO. The global burden of disease: 2008 update. Rilis Berita [serial online] 2008 (diunduh 13 Februari 2014). Tersedia dari: URL: HYPERLINK http://www.Who.Int/Mediacentre/Factsheets/Fs315/ En/.

9. KEMENKES RI. Riset kesehatan dasar 2010. Jakarta: Kementrian Kesehatan RI; 2010.

10. Setiyanto H. Pola sensitifitas kuman PPOK eksaserbasi akut yang mendapat pengobatan Echinacea purpura dan antibiotik siprofloksasin. Jurnal respirologi Indonesia. 2008;13(2).

11. Shinta. Studi penggunaan antibiotik pada eksaserbasi akut penyakit paru obstruktif kronik: studi pada pasien IRNA Medic di Ruang Paru Laki dan Paru Wanita RSU Dr. Soetomo Surabaya (skripsi). Surabaya: Universitas Airlangga; 2007.

12. Yolandha D. Pola dan sensitiviti kuman pada penderita PPOK eksaserbasi akut yang dirawat di bangsal paru RSUP Dr. M. Djamil Padang periode 1 Januari 2009 - 31 Desember 2011 (tesis). Padang: Universitas Andalas; 2012. 
13. Rahmatika A. Karakteristik penderita penyakit PPOK yang di rawat inap di RSUD Aceh Tamiang (skripsi). Medan: Universitas Sumatera Utara; 2009.

14. Suradi. Pengaruh rokok pada penyakit paru obstruktif kronik (PPOK) tinjauan patogenesis, klinis, dan sosial. pidato pengukuhan guru besar Pulmonologi dan IImu Kedokteran Respirasi Fakultas Kedokteran Universitas Sebelas Maret; 2007.

15. Amin M. PPOM: polusi udara, rokok dan alfa-1 antitripsin. Surabaya: Airlangga University Press; 1996.
16. Perhimpunan Dokter Paru Indonesia (PDPI).

Penyakit paru obstruktif kronik (PPOK). pedoman diagnosis \& penatalaksanaan di Indonesia. Rilis Berita [serial online] 2003 (diunduh 14 Februari 2014). Tersedia dari: URL: HYPERLINK http://www.Klikpdpi.Com/Konsensus/ Konsensusppok/Ppok.Pdf.

17. Prabaningtyas $O$. Hubungan antara derajat merokok dengan kejadian PPOK (skripsi). Surakarta: Universitas Sebelas Maret; 2010.

18. Nugraha I. Hubungan derajat berat merokok berdasarkan indeks Brinkman dengan derajat berat PPOK. Jurnal Kesehatan Profesional Islami. 2010;9. 